\title{
3 Research Square \\ Relationship between Cardiometabolic Risk and Physical Fitness in Young Girls with Aesthetic Professions
}

\section{Salime Lisboa ( $\nabla$ sa.lisboa@hotmail.com )}

Federal University of Rio Grande do Sul

\section{Alexandra Vieira Vieira}

Federal University of Rio Grande do Sul

Juliana Lopes Teodoro

Federal University of Rio Grande do Sul

Rochelle Costa

Faculdade Sogipa

\section{Franccesco Pinto Boeno}

Federal University of Rio Grande do Sul

\section{Juliano Farinha}

Federal University of Rio Grande do Sul

\section{Álvaro Reischak-Oliveira}

Federal University of Rio Grande do Sul

\section{Cláudia Gomes Bracht}

Federal University of Rio Grande do Sul

Giovani dos Santos Cunha

Federal University of Rio Grande do Sul

\section{Research Article}

Keywords: cardiometabolic risk, physical fitness, young girls, aesthetic professions

Posted Date: June 30th, 2021

DOI: https://doi.org/10.21203/rs.3.rs-653741/v1

License: (c) (i) This work is licensed under a Creative Commons Attribution 4.0 International License. Read Full License 


\section{Abstract}

Background: In the literature, professions that impose body standards for daily performance are designated as non-conventional professions (i.e. models, athletes, ballet dancers), with great emphasis on the female population. More than a job, it becomes a lifestyle to those inserted in this environment, thus, thousands of children and adolescents seek the inclusion and success in these professions due to financial and media gains. Such professions are associated to several health-related risk factors. The purpose of this study was to identify whether there is a relationship between physical fitness levels, cardiometabolic health markers, mental health and dietary habits in non-conventional professions.

Methods: The sample consisted of 41 female individuals aged between 14 and 24 years, divided in four groups, control group/ university students ( $U G=11)$, models $(M G=11)$, ballet dancers $(B G=11)$, and athletes group $(A G=8)$. Physical fitness outcomes (cardiorespiratory fitness, flexibility, maximal dynamic strength, muscular endurance and body composition); biochemical outcomes (high density lipoprotein [HDL], low density lipoprotein [LDL], total cholesterol [TC], fasting glucose [FG], fasting insulin [FI], C-reactive protein [CRP]), diet quality and mental health were evaluated.

Results: No impairments were observed in the health markers evaluated, both for health-related physical fitness and biochemical outcomes. Even with statistically significant differences between the groups for chronological age $(p=0.002)$, menarche $(p=0.004)$, career length $(p=0.001)$, height $(p=0.001)$, body mass index $(p=0.018)$, waistto-height ratio $(p<0.001)$, \% Fat $(p=0.020), V_{2 \text { peak }}(p=0.020)$, maximal dynamic strength of knee extensors $(p=0.031)$ and elbow flexors $(p=0,001)$ and flexibility $(p<0.001)$, all these values are within the normal range for health.

Conclusion: The professions analyzed do not seem to interfere in the physical and metabolic health of the girls assessed. However, regarding mental health, the evaluated age group was susceptible to depressive symptoms.

\section{Introduction}

Body appearance and the pursuit of beauty conception have been directly associated with health since the 19th century, and nowadays, with success. Beauty has been treated/discussed in society since ancient Greece, in the Ancient Olympic Games it was already possible to observe an incitement to body strength and beauty, with the ideology of body standards required by the society, which already exalted the benefits that the physical exercise practice brought to the body (1-3). Over time, changes have occurred in these body standards, reflecting traditions and customs of specific historical moments. It is also possible to realize that when searching for standardized bodies, the society considers that beautiful bodies are strongly linked to health, with exploration and enhancement of the female public appearance (4). Faced with that, some professions gained prominence in the world scenario, as a consequence of an unconventional daily life to a great part of the world population, using aesthetic standards and high levels of daily performance, thus formatting body measures to act in the professions of models, athletes and ballet dancers. These individuals who have daily occupations related to aesthetics (particularly related to their body shape) are disproportionately exposed to modifiable (frequent measurements of body parameters, weight and body shape control) and unmodifiable (height) daily charges (1).

The beginning of these professions primarily occurs in childhood, with wide dedication during adolescence (10 to 19 years), a transition period between phases characterized by physical, metabolic and mental changes (5), and 
also by the search for economic independence and social inclusion. The groups of non-conventional professions are selected for their aesthetics, meeting previously established measurements and body composition standards (low body weight accompanied by thinness), together with high daily performance. Many young women adopt daily routines and practices that can be harmful to their health in order to achieve inclusion and stability in these environments (6-8). Thus, the daily practices carried out by this public have been reported as behaviors that compromise health factors, including cardiometabolic, nutritional, physical and psychological risks due to the specific demands of each profession (9-13).

Health researchers recognize that some diseases and disorders are highly prevalent in occupational subgroups (compared to the general population) due to harmful exposure and daily vulnerability to maintain aesthetic standards. Moreover, it is undeniable that these professions are powerful and boost even more body standards and the media. The low body weight imposed in these professions can reduce fat percentage to levels below the normative values (12\% -15\% between 7-17 years old and 13-16\% between 18-25 years old, for women) $(14,15)$. Such reduction can lead to a series of health problems, such as changes in the lipid and metabolic profile (16), changes in the nutritional profile (food restriction, purging behaviors) causing eating disorders (such as anorexia and bulimia nervosa) (9), psychological disorders (17), along with changes in the physical exercise practice profile, with cases of increased exercise intensities in order to improve movement technique or accelerate body weight loss, as well as, in other cases, abandonment of physical exercise/sports practice, often caused due to injuries (18), overtrainning (19) or burnout syndrome, due to early specialization in the professions (12).

Although, on the one hand, these professions may present some health risk factors (20), on the other hand, studies with aesthetics-related professions show that despite the adopted behaviors, these groups have some protective factors to health (21). The practice of physical activities and exercises has achieved greater prestige as therapeutic and preventive tools for health promotion. When correctly applied, it proves to be a bioregulator of health indicators, which can cause an important connection between health and body standards.

For pediatric populations, the physical activity level is a demonstrative component of general health, thus avoiding chronic disorders (cardiovascular, endocrine, osteoarticular, neuromuscular and psychological diseases) and protecting against early mortality and morbidity (22). In this sense, it appears that the physical fitness level plays an important role in the performance of young people who have non-conventional professions (23), however, it is not yet clear whether the participation in these groups of professions is associated with unfavorable bodily changes. Therefore, the purpose of the present study was to compare the physical fitness, cardiometabolic risk factors, quality of life and depressive symptoms between young people belonging to non-conventional professions and a reference sample from the general population.

\section{Materials And Methods}

\section{Study design}

The present study is characterized as cross-sectional, consisting of four groups. Of these, three were composed of non-conventional professions (models, athletes and ballet dancers) and a control group (university students). All groups were submitted to the same tests (Figure 1).

\section{Subjects}


The sample consisted of 41 female teenagers and young adults aged 14 to 24 years who belonged to modeling agencies, sports teams, dance schools and universities from the city of Porto Alegre, Rio Grande do Sul, Brazil. The subjects were allocated according to their daily occupation: models group $(M G=11)$, ballet dancers group $(B G=11)$, athletes group $(A G=8)$ and university students group $(U G=11)$. Modeling agencies, sports clubs and dance schools also signed an assent form. The study was approved by the Research Ethics Committee of the Universidade Federal do Rio Grande do Sul - UFRGS (CAAE: 67847317.5.0000.5347), and was conducted according to the standards proposed by the Helsinki Declaration. The participants and their legal guardians (if participants are under 18 years old) were informed about the experimental protocol and the potential risks, providing written informed consent prior to participation (Figure 1).

\section{Body composition}

Height (HEI) and body mass (BM) measurements were carried out. With these values, body mass index (BMI) was calculated $\left(\mathrm{BMI}=\mathrm{BM}[\mathrm{kg}] / \mathrm{HEI}^{2}[\mathrm{~m}]\right)$. In addition, bone densitometry (BDM), fat mass, fat-free mass (FFM) and fat percentage (\%F) (Lunar Densitometer model DPX.L, "Dual Energy X-ray Absorptiometry") were evaluated in all participants. Data were processed by the system provided for each segment and the BDM results were expressed in $\mathrm{g} / \mathrm{cm}^{2}$.

\section{Cardiopulmonary exercise test (CPET)}

Peak oxygen consumption $\left(\mathrm{VO}_{2 \text { peak) }}\right.$ was evaluated by open circuit ergospirometry during a maximum treadmill run test. The highest value reached in the last minute of exercise was used. According to the manufacturer's instructions, the ergospirometry device (Quark CPET, Cosmed, Italy) was manually calibrated using the known concentrations of gases $\left(21 \% \mathrm{O}_{2}\right.$ as reference concentrations, $12 \% \mathrm{O}_{2}$ and $5.09 \% \mathrm{CO}_{2}$ for calibration). The individuals had the possibility and time to adapt to the treadmill (Quinton Instruments, Seattle, USA) and the ergospirometry device. The participants performed a single progressive maximal exercise test, which consisted of walking for 4 minutes at $4 \mathrm{~km} \cdot \mathrm{h}^{-1}$ followed by increases of $1 \mathrm{~km} \cdot \mathrm{h}^{-1}$ at each minute until exhaustion. The individuals were verbally encouraged during the test to reach their maximal performance. To verify an exhausting effort, each participant had to meet at least one of the following criteria after the end of the test: 1$) \mathrm{VO}_{2}$ plateau that was defined as an increase in $\mathrm{VO}_{2}$ of less than $2.4 \mathrm{~mL} . \mathrm{kg}^{-1} . \mathrm{min}^{-1}$ with a corresponding increase in exercise intensity $(24,25) 2$ ) obtainment of respiratory exchange ratio (RER) $\geq 1.0(26,27) 3$ ) perception of effort greater than 17 (very intense - Borg's scale of perceived exertion) (28). Heart rate was monitored using a heart rate monitor (FT1-POLAR). In addition, the individuals demonstrated evident signs of extreme physical effort at the end of the test, such as facial flushing, sweating, hyperpnea and unstable gait $(26,27)$. According to these criteria, $\mathrm{VO}_{2 \text { peak }}$ of all participants were considered valid. The ventilatory threshold (VT) and the ventilatory compensation point (VCP) were determined through ventilation (VE), respiratory equivalents $\left(\mathrm{VE} / \mathrm{VO}_{2}\right.$ and $\left.\mathrm{VE} / \mathrm{VCO}_{2}\right)$, partial pressure of carbon dioxide on exhalation $\left(\mathrm{PCO}_{2}\right)$ and partial pressure of oxygen on exhalation $\left(\mathrm{PO}_{2}\right)$ as a function of oxygen uptake. The criteria to determine VT and VCP were: VT was determined when there was a rapid increase in $\mathrm{VE} / \mathrm{VO}_{2}$ and $\mathrm{PO}_{2}$, without a concomitant increase in $\mathrm{VE} / \mathrm{VCO}_{2}$ and $\mathrm{PCO}_{2} ; \mathrm{VCP}$ was determined as the point that a rapid increase in $\mathrm{VE} / \mathrm{VCO}_{2}$ and a decrease in $\mathrm{PCO}_{2}$ were observed. VT and VCP were associated as the first and second non-linear increase in $\mathrm{VE}$ and $\mathrm{VCO}_{2}(29,30)$, respectively. All plots used in the determination of these points 
used breath by breath gross values. Two independent reviewers blindly determined VT and VCP following the criteria described above.

\section{One-repetition maximum and Muscular Endurance Tests}

Maximal strength was obtained by one-repetition maximum (1RM) test for bilateral knee extensors (KE) and bilateral elbow flexors (EF). Bilateral elbow flexion exercise was performed with barbells and dumbbells, whereas bilateral knee flexion exercise was performed in a strength training equipment (Konnen Gym). The subjects were familiarized with all procedures in a single session. On the test day, the participants carried out a warm-up for five minutes in a cycle ergometer, after having performed specific movements for the exercises of the tests. The maximum load of each individual was determined with no more than five attempts with five minutes of recovery between attempts. Performance time for each contraction (concentric and eccentric) was 1.5 seconds controlled by an electronic metronome (Quartz, CA, USA) (31). After the performance of 1RM test, the load corresponding to $60 \%$ of $1 \mathrm{RM}$ of each individual was fixed. The subjects performed the maximum number of possible repetitions until fatigue. The number of repetitions performed was used as a measure of muscular endurance (ME) (32).

\section{Flexibility}

To determine the flexibility of the hip, back and posterior muscles of the lower limbs, the sit and reach test was performed using the Wells bench. The subject remained barefoot, in a sitting position facing the equipment with the soles of the feet flat on the bench, stretched forward along the bench's metric demarcation, with outstretched arms and overlapping hands, seeking the greatest distance in three attempts, maintaining the value reached for 1 second. The highest value achieved was considered as a measure of flexibility (33).

\section{Blood analyses}

For the performance of the biochemical analyses of the study, the subjects should be fasting for eight hours. Initially, a 30-minute rest was performed, for further collection of $8 \mathrm{ml}$ of a vein in the antecubital region. The samples were stored (vacuitaner tubes with EDTA) and centrifuged ( $3.500 \mathrm{rpm}$ for 10 minutes), the plasma was aliquoted and frozen $\left(-80^{\circ}\right)$ for further analyses of fasting glucose (FG), fasting insulin (FI), total cholesterol (TC), triglycerides (TG), C-reactive protein (CRP) and high density lipoprotein (HDL). Glucose levels were analyzed by enzymatic colorimetric method (Cobas C111, Roche, Diagnostics, Basel, Switzerland). Low density lipoprotein (LDL) was calculated by Fridewald formula (34) (LDL:TC-HDL-TG/5). Plasma concentrations of FI were evaluated with commercial kits for humans (DRG International, Springfield, USA) by enzyme-linked immunosorbent assay (ELISA) according to the manufacturer's instructions. For the lipid variables, the Brazilian Guidelines of dyslipidemias and atherosclerosis prevention (35) were used with determined values for TC $(<170 \mathrm{mg} / \mathrm{dL}), \mathrm{HDL}$ $(>45 \mathrm{mg} / \mathrm{dL}), \mathrm{LDL}(<110 \mathrm{mg} / \mathrm{dL})$ and TG $(<90 \mathrm{mg} / \mathrm{dL})$. Values lower than $100 \mathrm{mg} / \mathrm{dL}$ and between 1.9 and $23.0 \mu \mathrm{UI} / \mathrm{mL}$ were used for $\mathrm{FG}$ and $\mathrm{Fl}$, respectively (36). For the inflammatory profile, the value of $<1 \mathrm{mg} / \mathrm{L}$ was used (32).

\section{Dietary record}


To evaluate dietary consumption and diet quality, a three-day dietary record was applied, describing daily dietary intake with the respective quantities. The record procedure was carried out as follows: each individual recorded all foods and beverages ingested in three days (two typical days and one atypical day of the weekend), also describing the eating schedule, quantities and when possible, the brand of the food. After filling in, all information was checked by a trained researcher, so that there would be no doubt about what was described. The dietary records were further calculated with the DietWin Professional Nutrition Software (Brubins CAS, Brazil).

\section{Depressive Symptoms}

Depressive symptoms assessment was carried out through the transcultural and self-applied CES-D depression scale, consisting of 20 statements on a Likert scale with four possible answers corresponding to number 1 (rarely or never - less than 1 day), 2 (few times - 1 to 2 days), 3 (a considerable time - 3 to 4 days) and 4 (all the time 5 to 7 days). Four items of the instrument are presented with positive sense (blocking the trend to repetitive responses), such items are reversely scored (higher scores indicate greater amount of depressive symptoms). The cutoff score for Brazilian adolescents and young adults is 15, in which individuals with this score or higher are considered at risk for depression (37).

\section{Statistical Analysis}

Normality of data distribution was evaluated by Shapiro Wilk test and homogeneity of variables was assessed by Levene test. Mean and standard deviation values were used for descriptive purposes. ANOVA one-way was used to analyze the differences between groups. LSD post hoc was used to establish the location of the differences between groups. Partial eta squared (n2) was calculated as a measure of effect size (ES). Values of $0.01,0.06$ and above 0.15 were considered small, medium and big, respectively (38). Kruskal-Wallis test was applied for the variables that did not present normal distribution. When the Kruskal-Wallis test was significant, pairwise comparisons were performed by Mann-Whitney U test for independent samples. Statistical analyses were performed with SPSS software (version 20.0, SPSS, Inc., IBM Company; NY, USA). The significance level adopted was $a<0.05$.

\section{Results}

Of the total sample, $A G$ presented the youngest age (years) between groups $(16.38 \pm 3.02, p=0.002)$, followed by BG (18.09 \pm 3.21$), M G(20.82 \pm 2.52)$ and UG (21.91 \pm 2.30$)$. For career duration (months), the highest values were presented by BG (147.27 \pm 65.97$)$, followed by $A G(132 \pm 44.44)$ and MG $(56.73 \pm 36.04)(p=0.001)$. Of the four groups, only three individuals of the $A G$ had not yet gone through the first menarche $(p=0.004)$. For nutritional and psychological counseling, UG presented 5 individuals with nutritional counseling and 7 with psychological counseling, MG had 7 and 4, BG had 2 and 5 and AG presented 6 and 6, respectively.

Statistically significant differences between groups were found for height, BMI, WHtR, \%Fat, fat mass, $1 \mathrm{RM}$ of KE and EF and flexibility ( $<<0.05)$. In BMI, MG presented the lowest values $(18.1 \pm 1.37, p=0.018)$ when compared to the other groups, however, it was within the expected for sex and age (39). For WHtR, all groups presented lower values than the cutoff point for cardiovascular health (40). In the 1RM of KE and EF, BG presented the lowest values in both limbs (1RM KE: $68.00 \pm 16.89, p=0.031$; $1 \mathrm{RM} E F: 13.91 \pm 2.39 p=0.001)$. On the other hand, in the 
values obtained for flexibility, AG $(50.38 \pm 5.71 \mathrm{~cm})$ and BG $(45.77 \pm 6.71 \mathrm{~cm})$ presented significantly greater values compared to the other groups (UG: $36.41 \pm 7.73$; MG: $31.32 \pm 9.96$ ). For BMI, 14 individuals (34\%) presented results below the normative values (41) for sex and age. As for flexibility, only 4 (10\%) girls presented values considered bad (42) for sex and age. Even without statistically significant values, for BDM, 26 individuals (63\%) showed results below the normative values $(43,44)$. The results regarding body composition, cardiorespiratory fitness, maximal dynamic strength, muscular endurance and flexibility are presented in table 1, whereas the individual responses are presented in table 4.

Table 1

Physical fitness according to the profession

\begin{tabular}{|c|c|c|c|c|c|c|}
\hline Variables & $\begin{array}{l}\text { UG } \\
(n=11)\end{array}$ & $\begin{array}{l}M G \\
(n=11)\end{array}$ & $\begin{array}{l}\text { BG } \\
(n=11)\end{array}$ & $\begin{array}{l}A G \\
(n=8)\end{array}$ & $\begin{array}{l}\mathrm{p} \\
\text { value }\end{array}$ & $\eta^{2}$ \\
\hline Body mass (kg) & $58.16 \pm 9.85$ & $54.62 \pm 4.52$ & $51.94 \pm 7.30$ & $50.91 \pm 5.35$ & 0.278 & 0.07 \\
\hline Height (m) & $1.66 \pm 0.08^{\mathrm{ab}}$ & $1.73 \pm 0.02^{\mathrm{a}}$ & $1.59 \pm 0.06^{\mathrm{ab}}$ & $1.60 \pm 0.06^{b}$ & $0.001^{\star}$ & 0.08 \\
\hline $\mathrm{BMI}\left(\mathrm{kg} / \mathrm{m}^{2}\right)$ & $20.9 \pm 2.04^{a}$ & $18.1 \pm 1.37^{b}$ & $20.5 \pm 2.75^{a}$ & $19.8 \pm 1.57^{\mathrm{ab}}$ & $0.018^{*}$ & 0.23 \\
\hline WHtR & $0.43 \pm 0.01^{\mathrm{a}}$ & $0.39 \pm 0.02^{b}$ & $0.43 \pm 0.04^{\mathrm{a}}$ & $0.44 \pm 0.02^{\mathrm{a}}$ & $0.001^{*}$ & 0.44 \\
\hline$\%$ Fat & $29.60 \pm 4.29^{a}$ & $28.35 \pm 4.12^{\mathrm{a}}$ & $29.01 \pm 4.81^{a}$ & $23.36 \pm 4.20^{\mathrm{b}}$ & $0.020^{*}$ & 0.23 \\
\hline Fat mass (kg) & $16.46 \pm 4.50$ & $14.98 \pm 2.61$ & $14.64 \pm 3.70$ & $11.71 \pm 3.07$ & 0.069 & 0.07 \\
\hline FFM (kg) & $40.20 \pm 5.70$ & $37.92 \pm 3.62$ & $35.74 \pm 5.41$ & $37.74 \pm 2.76$ & 0.187 & 0.12 \\
\hline $\operatorname{BDM}\left(\mathrm{g} / \mathrm{cm}^{2}\right)$ & $1.176 \pm 0.115$ & $1.122 \pm 0.098$ & $1.108 \pm 0.073$ & $1.132 \pm 0.120$ & 0.656 & 0.07 \\
\hline $\mathrm{Vo}_{2 \text { peak }}\left(\mathrm{ml} \cdot \mathrm{kg}^{-1} \cdot \mathrm{min}^{-1}\right)$ & $45.13 \pm 5.72^{a b}$ & $44.28 \pm 3.90^{\mathrm{b}}$ & $43.80 \pm 3.97^{b}$ & $50.08 \pm 3.62^{a}$ & $0.020^{\star}$ & 0.23 \\
\hline 1RM KE (kg) & $90.18 \pm 18.21^{a}$ & $78.09 \pm 17.59^{\mathrm{ab}}$ & $68.00 \pm 16.89^{b}$ & $79.94 \pm 11.73^{\mathrm{ab}}$ & $0.031^{\star}$ & 0.21 \\
\hline 1RM EF (kg) & $19.82 \pm 3.49^{a}$ & $16.73 \pm 2.28^{\mathrm{a}}$ & $13.91 \pm 2.39^{b}$ & $17.63 \pm 2.00^{\mathrm{a}}$ & $0.001^{\star}$ & 0.08 \\
\hline ME KE (rep) & $9.64 \pm 2.11$ & $10.09 \pm 3.91$ & $10.18 \pm 2.44$ & $10.25 \pm 1.75$ & 0.956 & 0.00 \\
\hline ME EF (rep) & $9.00 \pm 1.95$ & $7.82 \pm 2.32$ & $6.82 \pm 2.32$ & $8.63 \pm 3.02$ & 0.104 & 0.07 \\
\hline Flexibility (cm) & $36.41 \pm 7.73^{b}$ & $31.32 \pm 9.96^{b}$ & $45.77 \pm 6.71^{\mathrm{a}}$ & $50.38 \pm 5.71^{a}$ & $0.001^{*}$ & 0.00 \\
\hline \multicolumn{7}{|c|}{ 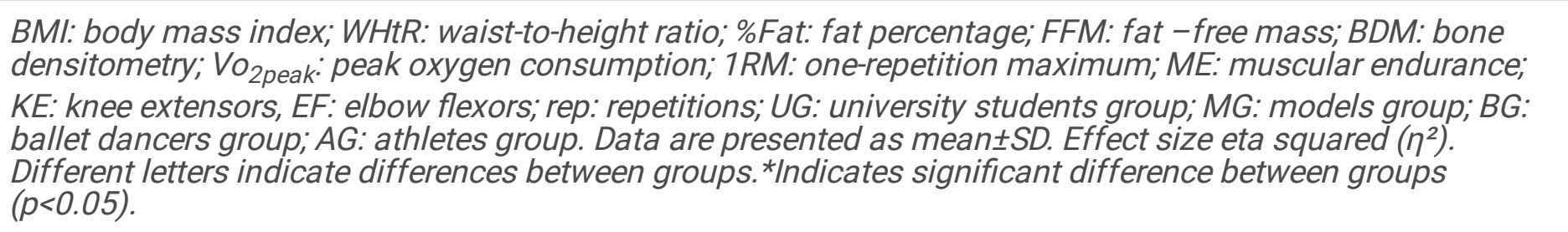 } \\
\hline
\end{tabular}


When analyzing the lipid (HDL, LDL, TG, CT) inflammatory (CRP) and glycemic (FG and FI) variables, no statistically significant differences were found between groups $(p>0.05)$. The effect size values found were HDL: $\eta^{2}=0.14$, LDL: $\eta^{2}=0.05$, TC: $\eta^{2}=0.02$, TG: $\eta^{2}=0.09$, FG: $\eta^{2}=0.12$, Fl: $\eta^{2}=0.07$, and CRP: $\eta^{2}=0.07$ (figure 2). The individual responses are presented in table 4. For HDL, only one individual ( $2 \%$ of the total) presented a nonnormative value $(>45 \mathrm{mg} / \mathrm{dL})$, for TC, 6 individuals $(15 \%,<170 \mathrm{md} / \mathrm{dL})$, for TG, 9 individuals $(22 \%,<90 \mathrm{mg} / \mathrm{dL})$, for $\mathrm{Fl}, 9$ individuals (22\%, from 1.9 to $230 \mu \mathrm{UI} / \mathrm{mL})$, and for CRP, 13 individuals $(31 \%,<1 \mathrm{mg} / \mathrm{dL})$.

\section{Dietary control}

No statistically significant differences were found between groups ( $p>0.05)$. The mean energy intake (kcal) presented by $A G$ is below the recommended (individually) for athletes who are exposed to the training loads described in this study (table 2).

Table 2

Dietary control variables through the three-day dietary record for university students (UG), models (MG), ballet dancers $(B G)$ and athletes (AG) in daily percentages (\%).

\begin{tabular}{|c|c|c|c|c|c|c|}
\hline & $\begin{array}{l}\text { UG } \\
(n=11)\end{array}$ & $\begin{array}{l}\text { MG } \\
(n=11)\end{array}$ & $\begin{array}{l}\text { BG } \\
(n=11)\end{array}$ & $\begin{array}{l}A G \\
(n=8)\end{array}$ & $\begin{array}{l}\mathrm{p} \\
\text { value }\end{array}$ & $\eta^{2}$ \\
\hline $\begin{array}{l}\text { Mean energy intake } \\
\text { (kcal) }\end{array}$ & $2003.0 \pm 658.9$ & $1926.2 \pm 686.7$ & $1713.9 \pm 460.4$ & $1684.2 \pm 459.0$ & 0.731 & 0.09 \\
\hline Carbohydrates (\%) & $49.1 \pm 4.5$ & $49.8 \pm 3.4$ & $50.8 \pm 6.8$ & $52.0 \pm 6.6$ & 0.924 & 0.05 \\
\hline Proteins (\%) & $20.3 \pm 3.3$ & $20.8 \pm 5.8$ & $19.4 \pm 3.4$ & $19.6 \pm 0.3$ & 0.791 & 0.24 \\
\hline Lipids (\%) & $29.5 \pm 3.5$ & $28.1 \pm 4.1$ & $29.7 \pm 4.9$ & $28.2 \pm 6.5$ & 0.842 & 0.07 \\
\hline
\end{tabular}

\section{Depressive Symptoms}

The results regarding the depressive symptoms score are presented in table 3 . No statistically significant differences were found between groups ( $p>0.05)$. All groups presented values above the cutoff points $(>15)$ for mental health. In addition, $53.6 \%$ of the girls were under psychological counseling. The individual responses are presented in table 4 . Of the total subjects of the study (41 individuals), $100 \%$ presented values that evidence a trend to depressive symptoms. 


\section{Table 3}

General depressive symptoms values obtained through the CES-D questionnaire for university students (UG), models (MG), ballet dancers (BG) and athletes (AG).

\begin{tabular}{|c|c|c|c|c|c|c|}
\hline & $\begin{array}{l}\text { UG } \\
(n=11)\end{array}$ & $\begin{array}{l}\text { MG } \\
(n=11)\end{array}$ & $\begin{array}{l}\text { BG } \\
(n=11)\end{array}$ & $\begin{array}{l}\text { AG } \\
(n=8)\end{array}$ & $\mathrm{p}$ value & $\eta^{2}$ \\
\hline Depressive symptoms & $39.00 \pm 5.22$ & $42.00 \pm 7.07$ & $41.60 \pm 5.20$ & $36.30 \pm 4.66$ & 0.127 & 0.13 \\
\hline
\end{tabular}

\section{Table 4}

Individual behavior for the anthropometric, physical fitness, biochemical and depressive symptoms variables.

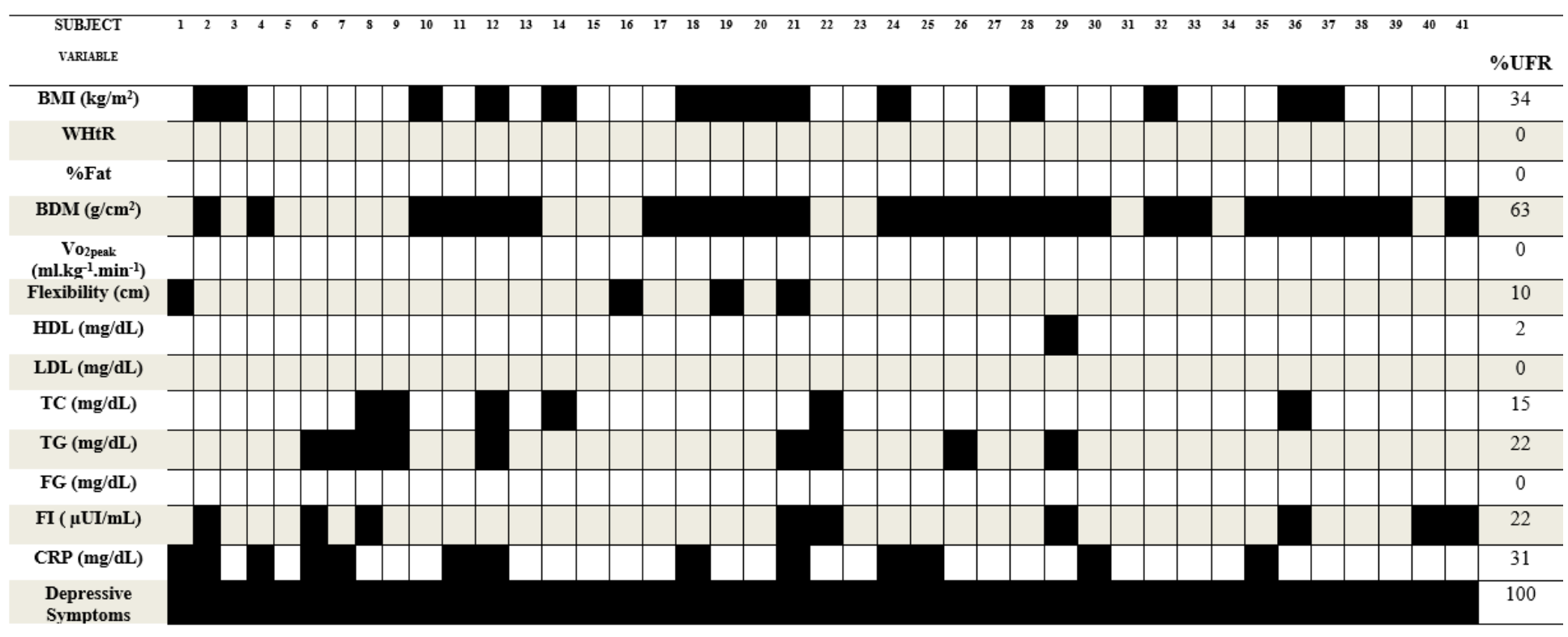

BMI: body mass index; WHtR: waist-to-height ratio; \%Fat: fat percentage; BDM: bone densitometry; Vo2peak: peak oxygen consumption; HDL: high density lipoprotein; LDL: low density lipoprotein; TC: total cholesterol; TG: triglycerides; FG: fasting glucose; FI: fasting insulin; CRP: C-reactive protein; \%UFR- Percentage of unfavorable response. Black squares: present unfavorable response.

\section{Discussion}

The atmosphere of the professions evaluated in our study are considered to be highly competitive $(20,45,46)$ due to the constant pressures on body shape (47). However, even though the professions evaluated in our study are related to several health risk factors, the results did not identify impairments associated with their professional 
choice for cardiometabolic health indicators $\left(\mathrm{VO}_{2 \text { peak }}\right.$, body composition, WHtR, LDL, TC and FG) and dietary patterns. In this context, the individuals evaluated in our study demonstrated a current health status for these properties.

In Western society it is clear that being overweight is directly linked to unpleasant feelings that cause body dissatisfaction. Reports of female adolescents depict that thin women are more attractive and healthy (48). However, such dissatisfaction with body weight and concerns to achieve an ideal beauty to fit in the body or professional framework are also associated with increased depressive symptoms (49). For the mental health variable, all participants of our study presented results above the cutoff values for the Brazilian female population ( $>15$ ), corroborating previous studies that evaluated the same populations individually, which also found trend results for depressive symptoms (50-52). In addition to the populations evaluated, there are evidences showing an increased prevalence of depressive disorders in the world population at increasingly earlier ages and twice as likely to occur in the female population (53). During stressful situations, the human body suffers internal and external threats that cause changes and adaptations in both the physical and behavioral profiles. Physiologically, there is a stimulation of the sympathetic nervous system and the hypothalamus-pituitaryadrenal axis, and psychologically, high levels of stress can also develop depressive symptoms (54). The individuals who comprised the sample of our study indicated that the demonstrated symptoms seem to be relatively common in the populations assessed, which is a warning sign, since the professions evaluated are the dreams of thousands of children and adolescents worldwide. The only group in our study that was not involved in any unconventional profession (UG) also demonstrated approximation of depressive symptoms in the same way as other groups. Adewuia et al. (55), in an epidemiological study with university students from different courses, found prevalence values between 15 and $25 \%$ of students with some type of manifestation of psychiatric disorders, with higher values for depressive disorders (prevalence of 8.3\%). Such values are attributed to stressor agents throughout university courses, varying with the student's level (beginner, intermediate or advanced) (56). Indeed, professional performance may not be markedly different for the prevalence of depressive symptoms to occur, according to the values found in our study (57).

Despite the daily particularities of the evaluated groups, an early professional initiation was observed in both groups of unconventional professions, with mean age of professional initiation at $19.5 \pm 3.4$ years and career lengths ranging from 4.7 years to 12.2 years, reaffirming that early professionalization seems to be unanimous for these professions. The highest values were found in BG and AG (the latter also presented the lowest mean age in our study, which is commonly found in gymnastics athletes) (58). Along with this, 7.32\% of AG participants had not yet gone through the first menarche. This result corroborates other studies in the area that evaluated late menstruation or amenorrhea in the same population (59), verifying that the age of first menarche for gymnastics athletes is delayed when compared to young people who do not exercise this modality, as well as aesthetic sports and modalities that demand a high level of performance, exposing young athletes to disorders at the level of the hypothalamic-pituitary-adrenal axis (60). Young gynecological age, emotional or mental stress and rapid increases in training load (to achieve excellence in motor coordination, strength and flexibility) together with low body weight can influence the dysfunction at the beginning of the menstrual cycle (59).

The greater mortality risk for overweight individuals (situation defined by WHO as BMI $25.0<30.0 \mathrm{~kg} / \mathrm{m}^{2}$ ) is widely exposed in the literature $(34,47,61)$, however, discussions on metabolic health variations among individuals with BMI considered normative $\left(18.5<25.0 \mathrm{~kg} / \mathrm{m}^{2}\right)$ are emerging $(39,62)$. In our study, we evaluated these components in order to seek a deeper understanding about body composition distribution and cardiometabolic impact in girls

Page 10/18 
involved in aesthetics-related professions. Cardiometabolic risk factors are due to biological changes (in lipid values, blood pressure, body weight, etc.) or related to lifestyle (inadequate diet, sedentary lifestyle, etc.).

Analyzing the individual responses, $24.39 \%$ (10 individuals) of the participants in our study were metabolically unhealthy, a definition given by Stefan et al. (62) as a combination of at least two predisposing parameters for metabolic syndrome (UG: 5, MG: 4, BG: 2, AG: 1). In this regard, the scientific literature addresses that individuals with normative body weight who are not metabolically healthy have similar risks of mortality and cardiovascular events than metabolically healthy obese individuals $(62,63)$.

In relation to the results obtained for \%Fat, of the total $n$ of our study, $48.78 \%$ of the girls had nutritional monitoring and it is speculated that the lowest values found in the AG are due to the combination of training and diet monitoring, since most of the AG (75\%) obtained nutritional counseling provided by the sports teams. In a previous study, Barlett et al. (64) found \%Fat values around $16.8 \%$, attributing the results to the aesthetic need of the sport as well as the balance between physical training and adequate nutrition.

Nonetheless, when verifying the mean energy intake ( $\mathrm{kcal})$ and the daily percentages of macronutrients indicated for adolescents (65), although the ingested values are considered adequate for all groups, the AG showed the lowest caloric intake of all groups. The Academy of Nutrition and Dietetics Dietitians of Canada (66) indicates that the daily caloric needs of athletes should be higher when compared to other groups, since the calculation of daily caloric needs must include the basal metabolic rate associated with the daily physical activity factor, in addition to the caloric expenditure promoted by physical exercise with estimated intensity in Mets. It is therefore suggested that the daily diet of the athletes has mean daily values below what is required for the amount and intensity of physical exercise performed in training.

Due to the previously mentioned particularities about the professions evaluated in this study, the concern with the health of these populations gains greater relevance on a daily basis due to the difficulties faced in this age group and the historical daily pressure on the female body. Nowadays, healthy eating and physical exercise benefits are very widespread through the media, which may be assisting in the search for professionals for better day-to-day management of the professions approached. Therefore, we believe that the combination of good dietary intake along with physical exercise practice demonstrated by the groups may be helping the health status of the individuals in physical and metabolic parameters, contradicting the idea that these professions present a risk to the physical and metabolic health of adolescents.

\section{Conclusion}

Based on the results found in our study, we observed that the professions analyzed and their aesthetic connection do not seem to interfere with the physical and metabolic health of the girls evaluated. However, all groups showed trends of decreasing mental health values. The comparison between groups showed great similarity in aspects of physical fitness and biochemical variables, regardless of whether the individuals had unconventional professions or not. However, even achieving satisfactory results, we believe that the populations involved need to be monitored daily since the age group (adolescence and young adults) is a period of formation and consolidation of life issues, in order to avoid future health problems. To our knowledge, this is the first study to evaluate the main professions considered at risk (models, ballet dancers and gymnasts) seeking to know the health indicators profile of these publics, comparing them with girls who do not work in unconventional professions. 


\section{Abbreviations}

Models group (MG), ballet dancers group (BG), athletes group (AG), university students group (UG), height (HEI), body mass (BM), body mass index (BMI), bone densitometry (BDM), fat-free mass $(F F M)$, fat percentage $(\% F)$, Cardiopulmonary exercise test (CPET), peak oxygen consumption $\left(\mathrm{VO}_{2 \text { peak), }}\right.$ United States (USA), respiratory exchange ratio (RER), one-repetition maximum (1RM), knee extensors (KE), elbow flexors (EF), muscular endurance (ME), fasting glucose ( $F G)$, fasting insulin (FI), total cholesterol (TC), triglycerides (TG), C-reactive protein (CRP), high density lipoprotein ( $\mathrm{HDL}$ ), low density lipoprotein (LDL), unconventional profession (UG),

\section{Declarations}

\section{Ethics approval and consent to participate:}

The study was approved by the Research Ethics Committee of the Universidade Federal do Rio Grande do Sul UFRGS (CAAE: 67847317.5.0000.5347), and was conducted according to the standards proposed by the Helsinki Declaration. The participants and their legal guardians (if participants are under 18 years old) were informed about the experimental protocol and the potential risks, providing written informed consent prior to participation.

\section{Consent for publication}

Not applicable.

\section{Availability of data and materials}

The datasets used and/or analysed during the current study are available from the corresponding author on reasonable request.

\section{Competing interests}

The authors declare that they have no competing interests.

\section{Funding:}

The authors were supported by a scholarship from CNPq (Brazilian Council of Science and Technology) and CAPES (Coordination for the Improvement of Higher Level - or Education - Personnel).

\section{Authors' contributions:}

S.C.L., G.S.C. and A.R.O. contributions to conception and design, S.C.L, A.V, J.L.T, R.C, F.P.B, C.G.B contributions to acquisition of data, all authors contributions to analysis and interpretation of data, drafting the article or revising it critically for important intellectual content an and final approval of the version to be published. 


\section{Acknowledgements}

Not applicable.

\section{Authors' information (optional)}

Not applicable.

\section{References}

1. Vigarello G. História da Beleza: O corpo e a arte de se embelezar, do Renascimento aos dias de hoje. Rio de Janeiro: Ediouro; 2015.

2. Araujo DC de, Leoratto D. Alterações da silhueta feminina: a influência da moda. Rev Bras Ciênc Esporte. setembro de 2013;35(3):717-39.

3. Santos SF dos, Salles AD. Antropologia de uma academia de musculação:um olhar sobre o corpo e um espaço de representação social. Rev bras Educ Fís Esporte. junho de 2009;23(2):87-102.

4. Zancu SA, Rodgers RF, Enea V. Self-determined motivation for eating behavior regulation and sociocultural influences among Romanian fashion models. Body Image. dezembro de 2019;31:150-9.

5. Tanner JM. Growth at adolescence. $2^{\circ}$ ed. Springfield: Thomas; 1962.

6. Zancu SA, Enea V. Eating disorders among fashion models: a systematic review of the literature. Eat Weight Disord. 2017;22:395-405.

7. Rodrigues AM, Costa RF, Fisberg M. Características antropométricas de candidatas em concurso seletivo de uma grande agência de São Paulo. Centro de Estudos e Pesquisa Sanny. 2008;

8. Braggion GF, Matsudo SMM, Matsudo VKR. Consumo alimentar, atividade física e percepção da aparência corporal em adolescentes. Rev Bras Ciên e Mov Brasília. 2000;8(1):15-21.

9. Fairburn CG, Harrison PJ. Eating disorders. The Lancet. fevereiro de 2003;361(9355):407-16.

10. Burckhardt P, Wynn E, Krieg M-A, Bagutti C, Faouzi M. The Effects of Nutrition, Puberty and Dancing on Bone Density in Adolescent Ballet Dancers. J Dance Med Sci. 2011;15(2):51-60.

11. Constantini NW, Dubnov G, Lebrun CM. The Menstrual Cycle and Sport Performance. Clin Sports Med. abril de 2005;24(2):e51-82.

12. Gustafsson H, Lundkvist E, Podlog L, Lundqvist C. Conceptual Confusion and Potential Advances in Athlete Burnout Research. Percept Mot Skills. dezembro de 2016;123(3):784-91.

13. Smethurst W, Wales J, Arcelus J. Puff the magic slimmer? Eur Eat Disord Rev. novembro de 2010;18(6):4313.

14. BRISTISH JOURNAL OF NUTRITION. Tabela de percentual de gordura para crianças e adolescentes de 7 a 17 anos. British Journal of Nutrition. 1990;63.

15. Pollock ML, Wilmore JH. Exercícios na Saúde e na Doença. In: Avaliação e Prescrição para Prevenção e Reabilitação. MEDSI Editora Médica e Científica Ltda.; 1993. p. 233-362.

16. Meira T de B, Nunomura M. Interação entre leptina, ginástica artística, puberdade e exercício em atletas do sexo feminino. Rev Bras Ciênc Esporte. setembro de 2010;32(1):185-99. 
17. The McKnight Investigators. Risk Factors for the Onset of Eating Disorders in Adolescent Girls: Results of the McKnight Longitudinal Risk Factor Study. Am J Psychiatry. fevereiro de 2003;160(2):248-54.

18. Schwellnus M, Soligard T, Alonso J-M, Bahr R, Clarsen B, Dijkstra HP, et al. How much is too much? (Part 2) International Olympic Committee consensus statement on load in sport and risk of illness. Br J Sports Med. setembro de 2016;50(17):1043-52.

19. Faigenbaum AD. OVERTRAINING IN YOUNG ATHLETES: How Much Is Too Much? ACSMs Health Fit J. julho de 2009;13(4):8-13.

20. Lisboa S, Delevatt R, Kruel L. Padrões de Beleza, Saúde e Qualidade de Vida em Modelos de Passarela - uma Revisão de Literatura. Rev Bras Ciênc Saúde. 2015;19(3):241-6.

21. Lisboa SDC, Delevatti RS, Kanitz AC, Reichert T, Bracht CG, Vieira AF, et al. Health-Related Physical Fitness in Female Models. Health (N Y). 2016;08(02):163-72.

22. Petersen AMW, Pedersen BK. The anti-inflammatory effect of exercise. J Appl Physiol. abril de 2005;98(4):1154-62.

23. Biddle SJ, Gorely T, Marshall SJ, Murdey I, Cameron N. Physical activity and sedentary behaviours in youth: issues and controversies. J R Soc Promot Health. janeiro de 2004;124(1):29-33.

24. Midgley AW, McNaughton LR, Polman R, Marchant D. Criteria for Determination of Maximal Oxygen Uptake: A Brief Critique and Recommendations for Future Research. Sports Med. 2007;37(12):1019-28.

25. Rowland TW, Cunningham LN. Oxygen Uptake Plateau during Maximal Treadmill Exercise in Children. Chest. fevereiro de 1992;101(2):485-9.

26. Armstrong N, Welsman J. Peak oxygen uptake in relation to growth and maturation in 11- to 17-year-old humans. Eur J Appl Physiol. outubro de 2001;85(6):546-51.

27. Tolfrey K, Barker A, Thom JM, Morse Cl, Narici MV, Batterham AM. Scaling of maximal oxygen uptake by lower leg muscle volume in boys and men. J Appl Physiol. junho de 2006;100(6):1851-6.

28. Borg G. Escalas de Borg para a Dor e o Esforço Percebido. São Paulo: Manole; 2000.

29. Cannon D, Kolkhorst F, Buono M. On the Determination of Ventilatory Threshold and Respiratory Compensation Point via Respiratory Frequency. Int J Sports Med. março de 2009;30(03):157-62.

30. Whipp BJ, Ward SA, Wasserman K. Respiratory Markers of the Anaerobic Threshold. In: Tavazzi L, Di Prampero F, organizadores. Advances in Cardiology [Internet]. S. Karger AG; 1987 [citado 15 de julho de 2020]. p. 47-64. Disponível em: https://www.karger.com/Article/FullText/413438

31. Cadore EL, González-Izal M, Pallarés JG, Rodriguez-Falces J, Häkkinen K, Kraemer WJ, et al. Muscle conduction velocity, strength, neural activity, and morphological changes after eccentric and concentric training: Adaptations to eccentric and concentric loads. Scand J Med Sci Sports. outubro de 2014;24(5):e343-52.

32. Rana SR, Chleboun GS, Gilders RM, Hagerman FC, Herman JR, Hikida RS, et al. Comparison of Early Phase Adaptations for Traditional Strength and Endurance, and Low Velocity Resistance Training Programs in College-Aged Women: J Strength Cond Res. janeiro de 2008;22(1):119-27.

33. Charro MA, Bacurau RFP, Navarro F, Pontes Junior FL. Manual de avaliação física. São Paulo: Phorte; 2010.

34. Friedewald WT, Levy RI, Fredrickson DS. Estimationof the Concentrationof Low-Density LipoproteinCholesteroiln Plasma,Without Useof the PreparativeUltracentrifuge.:4. 
35. Précoma DB, Oliveira GMM de, Simão AF, Dutra OP, Coelho-Filho OR, Izar MC de O, et al. Updated Cardiovascular Prevention Guideline of the Brazilian Society of Cardiology - 2019. Arq Bras Cardiol [Internet]. 2019 [citado 29 de setembro de 2020]; Disponível em:

http://www.gnresearch.org/doi/10.5935/abc.20190204

36. Sociedade Brasileira de Diabetes. DIRETRIZES SOCIEDADE BRASILEIRA DE DIABETES. In Clannad Editora Científica; 2019.

37. Silveira DX, Jorge MR. Propriedades psicométricas da escala de rastreamento populacional para depressão CED-D em populações clínicas e não-clínicas de adolescentes e adultos jovens. Rev psiquiatr clín. $1998 ; 25(5): 251-61$.

38. Cohen J. Statistical Power Analysis for the Behavioral Sciences. $2^{\circ}$ ed. Hillsdale, NJ: Lawrence Erlbaum Associates Publishers; 1988. 281-285 p.

39. WHO WORLD HEALTH ORGANIZATION - WHO. Phisical Status: the use and interpretation of anthropometry. Technical Reporte Series: Geneva; 1995.

40. Savva S, Tornaritis M, Savva M, Kourides Y, Panagi A, Silikiotou N, et al. Waist circumference and waist-toheight ratio are better predictors of cardiovascular disease risk factors in children than body mass index. Int $J$ Obes. novembro de 2000;24(11):1453-8.

41. Sousa M das GB, Pinheiro MM, Szejnfeld VL, Castro CHM. Body Composition Parameters in Healthy Brazilian Women Differ From White, Black, and Hispanic American Women Reference Range. J Clin Densitom. julho de 2013;16(3):360-7.

42. Canada. Fitness and Amateur Sport, Canadian Association of Sports Sciences, Fitness Appraisal Certification and Accreditation Program. Canadian standardized test of fitness (CSTF): operations manual. $3^{\circ}$ ed. 1987.

43. Gordon CM, Bachrach LK, Carpenter TO, Crabtree N, El-Hajj Fuleihan G, Kutilek S, et al. Dual Energy X-ray Absorptiometry Interpretation and Reporting in Children and Adolescents: The 2007 ISCD Pediatric Official Positions. J Clin Densitom. janeiro de 2008;11(1):43-58.

44. Binkovitz LA, Henwood MJ. Pediatric DXA: technique and interpretation. Pediatr Radiol. janeiro de 2007;37(1):21-31.

45. Druss RG, Silverman JA. Body image and perfectionism of ballerinas. Gen Hosp Psychiatry. julho de 1979;1(2):115-21.

46. Filaire E, Bonis J. RELATIONSHIPS BETWEEN PHYSIOLOGICAL AND PSYCHOLOGICAL STRESS AND SALIVARY IMMUNOGLOBULIN A AMONG YOUNG FEMALE GYMNASTS '. 2003;13.

47. Lowenkopf EL, Vincent LM. The student ballet dancer and anorexia. Hillside Journal of Clinical Psychiatry. 1982;4(1):53-64.

48. Baluch B, Furnham A, Huszcza A. Perception of body shapes by anorexics and mature and teenage females. 1997;53(2):167-75.

49. Rierdan J, Koff E. Weight, weight-related aspects of body image, and depression in early adolescent girls. Adolescence. 1997;32(127):615-24.

50. Lisboa SDC, Delevatti RS, Kanitz AC, Schuch FB, Bracht CG, Kruel LFM. Quality of Life and Depressive Symptoms in Female Models. Health (N Y). 2016;08(11):1040-8.

51. Bettle N, Bettle O, Neumärker U, Neumärker K-J. Body Image and Self-Esteem in Adolescent Ballet Dancers. Percept Mot Skills. agosto de 2001;93(1):297-309. 
52. Yang J, Peek-Asa C, Corlette JD, Cheng G, Foster DT, Albright J. Prevalence of and Risk Factors Associated With Symptoms of Depression in Competitive Collegiate Student Athletes: Clin J Sport Med. novembro de 2007;17(6):481-7.

53. Kuehner $\mathrm{C}$. Why is depression more common among women than among men? Lancet Psychiatry. fevereiro de 2017;4(2):146-58.

54. Mineka S, Zinbarg R. A contemporary learning theory perspective on the etiology of anxiety disorders: It's not what you thought it was. Am Psychol. 2006;61(1):10-26.

55. Adewuya AO, Ola BA, Aloba O0, Mapayi BM, Oginni OO. Depression amongst Nigerian university students: Prevalence and sociodemographic correlates. Soc Psychiatry Psychiatr Epidemiol. agosto de 2006;41(8):674-8.

56. Rotenstein LS, Ramos MA, Torre M, Segal JB, Peluso MJ, Guille C, et al. Prevalence of Depression, Depressive Symptoms, and Suicidal Ideation Among Medical Students: A Systematic Review and Meta-Analysis. JAMA. 6 de dezembro de 2016;316(21):2214.

57. Ibrahim AK, Kelly SJ, Adams CE, Glazebrook C. A systematic review of studies of depression prevalence in university students. J Psychiatr Res. março de 2013;47(3):391-400.

58. Granacher U, Borde R. Effects of Sport-Specific Training during the Early Stages of Long-Term Athlete Development on Physical Fitness, Body Composition, Cognitive, and Academic Performances. Front Physiol. 16 de outubro de 2017;8:810.

59. Czajkowska M, Plinta R, Rutkowska M, Brzęk A, Skrzypulec-Plinta V, Drosdzol-Cop A. Menstrual Cycle Disorders in Professional Female Rhythmic Gymnasts. Int J Environ Res Public Health. 25 de abril de 2019;16(8):1470.

60. Guebels CP, Kam LC, Maddalozzo GF, Manore MM. Active Women before/after an Intervention Designed to Restore Menstrual Function: Resting Metabolic Rate and Comparison of Four Methods to Quantify Energy Expenditure and Energy Availability. Int J Sport Nutr Exerc Metab. fevereiro de 2014;24(1):37-46.

61. Flegal KM, Kit BK, Orpana H, Graubard BI. Association of All-Cause Mortality With Overweight and Obesity Using Standard Body Mass Index Categories: A Systematic Review and Meta-analysis. JAMA. 2 de janeiro de 2013;309(1):71.

62. Stefan N, Schick F, Häring H-U. Causes, Characteristics, and Consequences of Metabolically Unhealthy Normal Weight in Humans. Cell Metab. agosto de 2017;26(2):292-300.

63. Stefan N, Fritsche A, Häring H-U. Mechanisms Explaining the Relationship Between Metabolically Healthy Obesity and Cardiovascular Risk. J Am Coll Cardiol. junho de 2014;63(24):2748-9.

64. Bartlett JD, O'Connor F, Pitchford N, Torres-Ronda L, Robertson SJ. Relationships Between Internal and External Training Load in Team-Sport Athletes: Evidence for an Individualized Approach. Int J Sports Physiol Perform. fevereiro de 2017;12(2):230-4.

65. Gianinni DT. Recomendações nutricionais do adolescente. Adolescência \& Saúde. 2007;4(1).

66. ACADEMY OF NUTRITION AND DIETETICS DIETITIANS OF CANADA. Nutrition and Athletic Performance Medicine \& Science in Sports \& Exerc. 2016;116(3):501-28.

\section{Figures}




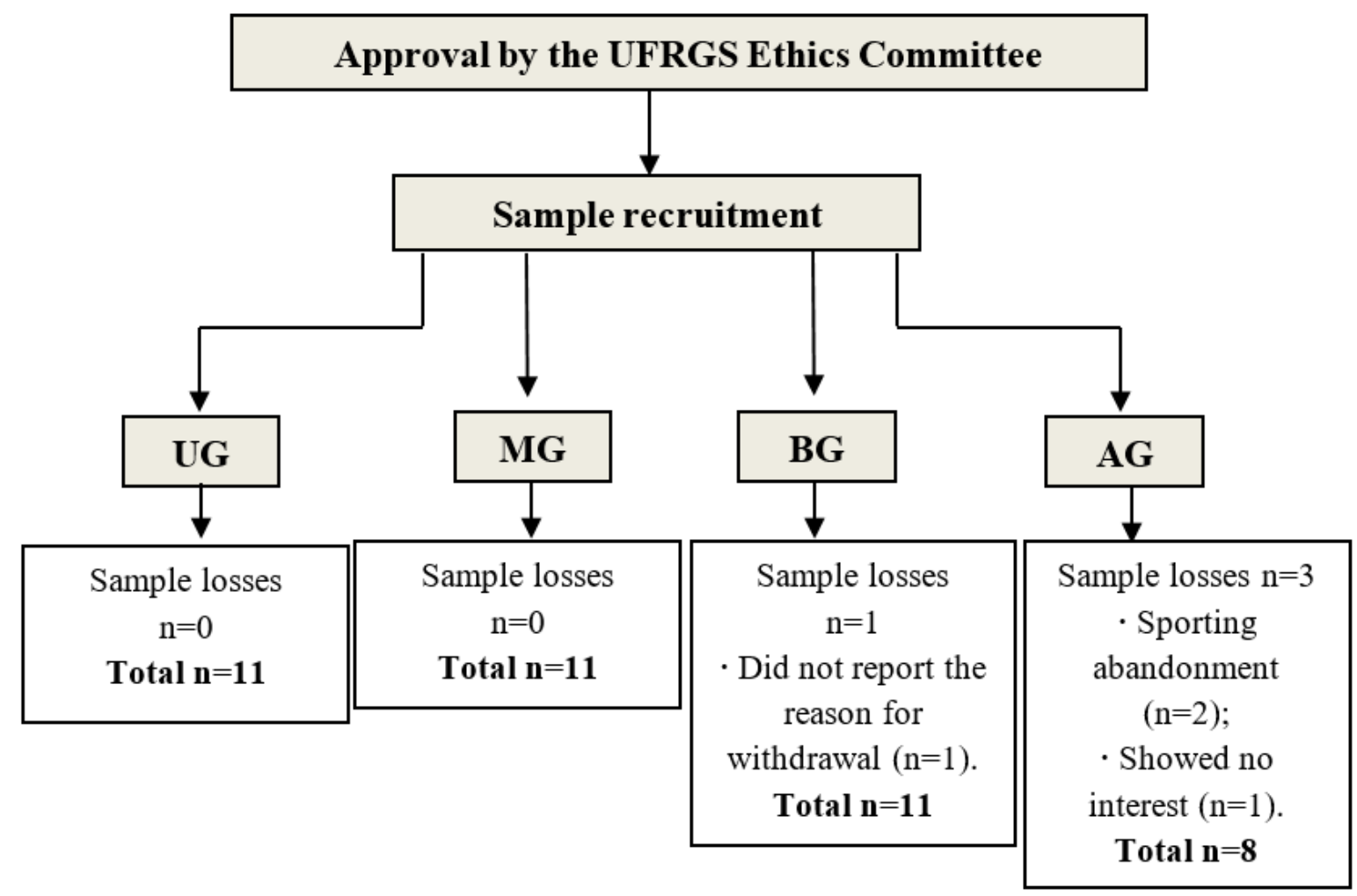

\begin{tabular}{|c|c|c|}
\hline \multicolumn{3}{|c|}{ Familiarizations } \\
\hline \multicolumn{3}{|c|}{$\downarrow$} \\
\hline \multicolumn{3}{|c|}{ Assessments } \\
\hline $\begin{array}{c}\text { Step 1: } \\
\text { • Consent form; } \\
\text { - Anamnesis; } \\
\text { • Questionnaires; } \\
\text { • Flexibility; } \\
\text { - Cardiorrespiratory } \\
\text { fitness. }\end{array}$ & $\begin{array}{c}\text { Step 2: } \\
\text { - Body composition } \\
\text { assessment; } \\
\text { - Maximal dynamic } \\
\text { strength; } \\
\text { - Muscular } \\
\text { endurance. }\end{array}$ & $\begin{array}{c}\text { Step 3: } \\
\text { • Blood samples; } \\
\text { • Delivery of } \\
\text { dietary records. }\end{array}$ \\
\hline
\end{tabular}

Figure 1

Study Overview Flowchart of the experimental design of the study. 
2A)

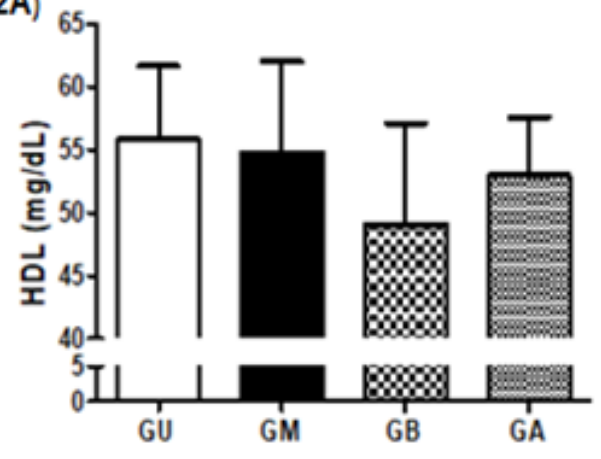

2C)

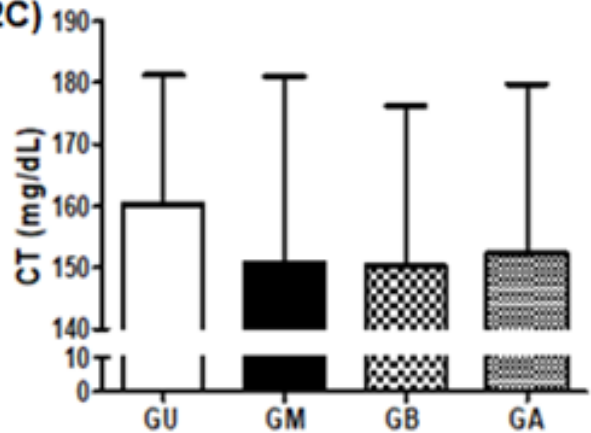

2E)
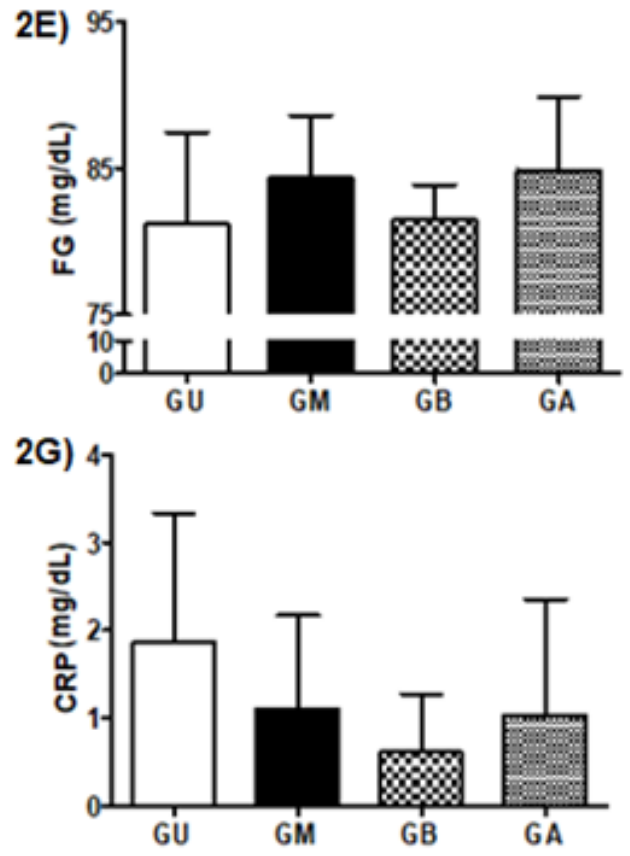

2B)

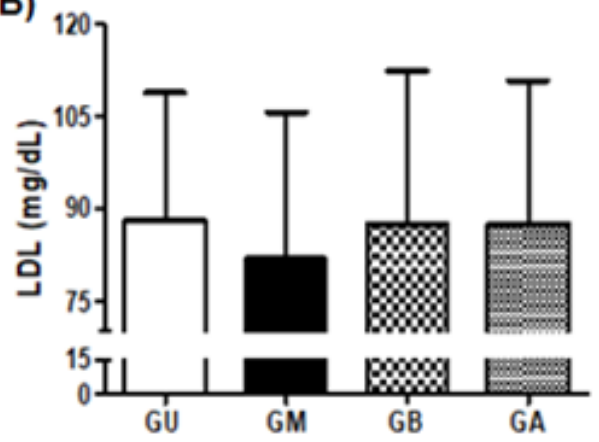

2D)

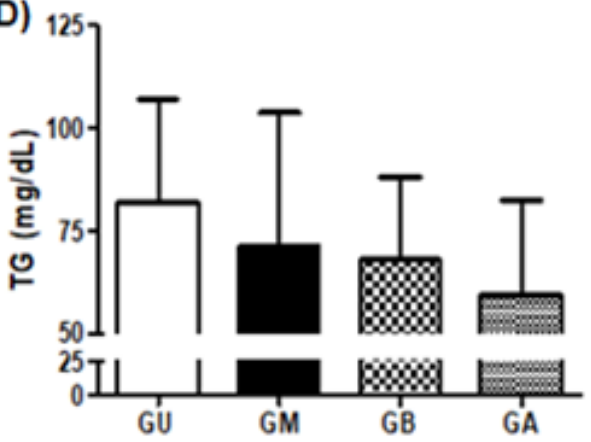

2F)

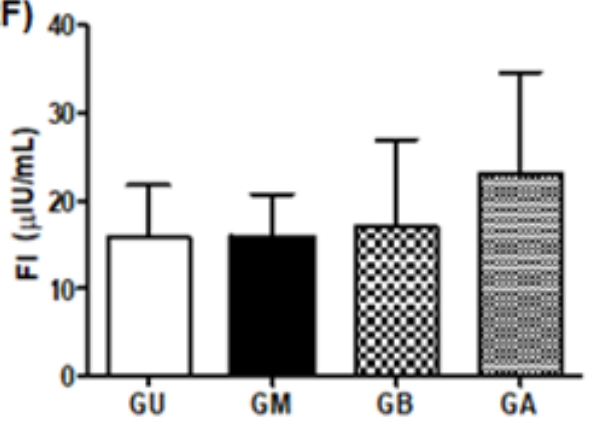

\section{Figure 2}

2A) High density lipoprotein (HDL); 2B) Low density lipoprotein (LDL); 2C) Total Cholesterol (TC); 2D) Triglycerides (TG); 2E) Fasting glucose (FG); 2F) Fasting insulin (FI); 2G) C-reactive protein (CRP). UG: university students group; MG: models group; BG: ballet dancers group; AG: athletes group. Data are presented as mean $\pm S D$. 